University for Business and Technology in Kosovo

UBT Knowledge Center

Nov 7th, 9:00 AM - 5:00 PM

\title{
Architects role in change influenced by technology and increasing urban data (BIM, GIS and CODES) from global and local perspective
}

\author{
Ferhat Bejtullahu \\ University for Business and Technology, ferhatbej@ubt-uni.net.com \\ Violeta Nushi \\ University of Prishtina, violeta.nushi@uni-pr.edu \\ Enis Jakupi \\ Universiteti Shtetëror i Tetovës, e.jakupi78@hotmail.com
}

Follow this and additional works at: https://knowledgecenter.ubt-uni.net/conference

Part of the Architecture Commons

\section{Recommended Citation}

Bejtullahu, Ferhat; Nushi, Violeta; and Jakupi, Enis, "Architects role in change influenced by technology and increasing urban data (BIM, GIS and CODES) from global and local perspective" (2015). UBT International Conference. 59.

https://knowledgecenter.ubt-uni.net/conference/2015/all-events/59

This Event is brought to you for free and open access by the Publication and Journals at UBT Knowledge Center. It has been accepted for inclusion in UBT International Conference by an authorized administrator of UBT Knowledge Center. For more information, please contact knowledge.center@ubt-uni.net. 


\title{
Architects role in change influenced by technology and increasing urban data (BIM, GIS and CODES) from global and local perspective
}

\author{
Ferhat Bejtullahu ${ }^{1}$, Violeta Nushi² ${ }^{2}$ Enis Jakupi ${ }^{3}$ \\ ${ }^{1}$ Fakulteti i Arkitekturës dhe Planifikimit Hapësinorë; UBT \\ Lagjja Kalabria p.n.; Prishtinë, Kosovë \\ ${ }^{2}$ Fakulteti i Ndërtimtarisë dhe Arkitekturës; Universiteti i Prishtinës 'Hasan Prishtina' \\ Bregu i Diellit, p.n.; Prishtinë, Kosovë \\ ${ }^{3}$ Fakulteti i Shkencave të Zbatura; Universiteti Shtetëror i Tetovës \\ Rr. Ilindenit, p.n.; Tetovë, Maqedoni \\ ferhatbej@ubt-uni.net.com¹, violeta.nushi@uni-pr.edu², e.jakupi78@hotmail.com³
}

\begin{abstract}
Architects are highly dependent from technology and the need to have integrated tools that also allows them to create models. The main objective of this research is to identify architects role in change influenced by technology and increasing urban data (BIM, GIS and CODES). Architects role in given context is analyzed from global and local perspective. Specific objective of this research is to investigate the use of BIM and urban data from perspective an architect, analyze reduced architects' influence, owners crush design fees and possibilities to take back design control. Literature review, daily spontaneous interviews with participants in the planning and design phase of Prishtina projects and three interviews with experts in information technology have been conducted. Understanding role in change influenced by technology and increasing urban data would minimize misunderstandings and provide architects and each participant in construction industry with clear responsibilities.
\end{abstract}

Key-words: Influence, Architects, Technology, Change

\section{Introduction}

As architects and planners, we accept a particular responsibility and have an exclusive opportunity to lead the world in the search for long-term, practical solutions that take advantage of our existing urban assets in a sustainable, smart way. Architects primary role and desire is to design. Providing services of design and construction of buildings and the space creating within the site surrounding the buildings, architects have as their principal purpose human occupancy or use - place creating. Many design firms are moving towards compensation models based on the full value created, rather than on hours spent. Many architects chose to move into real estate (property) development, corporate facilities planning, project management, construction management, interior design or other related fields. This diversity together with the development of industrialized buildings has contributed to modified work processes, shifts in roles and new ways of communicating. Both the capacity of the new technology and the organizational change are important in order to implement the technology successfully (Day, 1996).

By having urban data (BIM, GIS and CODES) requirements provided instantly, it empowers architects to study many scenarios with the knowledge of how it aligns with city planning. This technology gives architects ability to be more intuitive (which most prefer when designing) with results that are more contextual using computer to do what it does best while allowing the architects more time to do what they do best which is innovation, creativity, and making buildings that improve our communities and peoples' lives.

Architectural and urban design produces spaces and places to experience and live in; participants in every phase of the construction project have to reach professional knowledge of each design phase. Institutions responsible for construction industry, have to design det ailed a work plan for each role explaining how the urban data systems and BIM should be used, why and what expected outcome is. 
Collaboration is also a key requirement of our system. Collaboration around a shared model allows each expert to maintain their specialized domain model, while providing stakeholders with a holistic view of the entire project during the early design stages. Our tools provide decision support by computing key metrics such as construction cost and life-cycle operating cost in near real-time.

Real estate developers, land-use specialists, and architects were spending considerable time gathering and consolidating data from a multitude of sources to understand development potential and constraints. Furthermore, this process is repeated for every candidate site by every interested developer. The evolving use of technical platforms and BIM to increase the quality, shorten the project time and come up with cheaper solutions (Tweed, 2001) is main reason for choosing this topic with aim of giving contribution in understanding architects role in this process.

Literature review, spontaneous discussions and interviews are done to evaluate the influence and impact of BIM, urban data and technology on the architects' role and work process in global and local context. Evaluating how this change affects the collaboration and communication between architects and other actors within the project and evaluate how architects use BIM and urban data to attain architectural values, style and design quality enabled conclusions and recommendations.

\section{Objectives and Metodology}

Main objective of this research is to identify architects role in change influenced by technology and increasing urban data (BIM, GIS and CODES). Another objective is to identify how technology and increasing urban data affect role of architects in the practical reality.

Specific objectives are to analyze reduced architects' influence, owners crush design fees and possibilities to take back design control.

Having in mind objectives mentioned above, the following research questions are addressed:

- How use of BIM and a urban data impact on the changing architect's?

- How do BIM, GIS and CODES affect the collaboration and communication between architects and other particip ants within the project in global and local conditions?

- How can the architects and institutions take back design control, architectural values, style and design quality?

Methodology used in this research is chosen having in mind the research question. Different alternatives were considered on how to gather the empirical data. The literature on BIM, GIS and CODES is bigger than the scope of this chapter. Face-to-face interviews allowed to make changes in the order of the questions and to add sub-questions to get new inputs and a deeper explanation and understanding of the interviewees experience in the matter. Survey is used to ask how the role of the architect looks like today and how it will change with the implementation of BIM, GIS and CODES. Three researchers and experts were interviewed. They were selected based on their knowledge and expertise in this field. All of the three interviewees have a long experience in architectural practice; two of them have more than 15 years of experience in industrial building.

\section{GENERAL INFORMATION}

\subsection{Background and context}

Under pressure coming from construction industry and technology in recent decades we have seen the rise of specializations within the architecture profession. Owners squeeze design fees down to nearly unsustainable levels. As a result, the required time to fully explore detail complexities has disappeared. Construction documents as a whole are nowhere as complete as they were in past decades. Many architects selected to move into real estate (property) development, corporate facilities planning, project management, construction management, interior design or other related fields. Context is a primary consideration in architectural design. By creating a data-rich virtual environment, our tools can help architects assess the fitness of a proposed design in relation to its context. This contextual awareness is especially valuable when performing energy modeling, day lighting analysis, and traffic simulation. 
Identity of a virtual place depends only on the creativity of the designer (Relph, 2007). Usually, in practice imagined spaces have to accept the conditions of real places if they are to be agreed correctly - harmonized. The software industry has been evolving and influencing architects at an exponential rate since its inception three decades ago. How can software engineering return the favor to architecture and help improve the scale economies of our industry? How can we amplify innovations in order to meet the twin challenges of urbanization and sustainability? Seeking answers to these questions motivates as to undertake this research in local and international level.

With emerging technologies rapidly changing our daily lives, the questions related to the architect's roles and responsibilities are also changing. Emerging technology can help streamline the design protocol while also providing a more intelligent fight to hold design which is sometimes lost to value engineering and questions asked too late in the process.

Kosova as new state is in the process of creating urban data (BIM, GIS and CODES) requirements system. We have data from firms trained and certified by prestigious and well-known standards and institutions to offer high quality services with a qualified and diverse staff certified by ISO 9001:2008 for geodetic services, GIS and Software Development as well as Project Management. Licensed from Kosova Cadastral Agency for cadastral and property rights services and from MAFRD for compilation of forest management plans.

Kosova is in the creation process of the technical regulations known as the "Unified Building Code of Republic of Kosova." This Code establishes technical requirements for the design, construction, alteration, repair, reconstruction, and demolition of buildings and other construction objects within the Republic of Kosova.

The purpose of the Code is to establish the minimum requirements to safeguard the public health, safety and general welfare through the necessary resistance of the structure of means of egress facilities, equilibrium and stability, sanitation, management of construction waste, adequate light and ventilation, energy efficiency and savings measures, and safety to life and property from fire and other hazards attributed to the built environment and to provide safety to fire fighters and emergency responders during emergency operations, as well as any other technical requirement that is considered a relevant technical issue by its nature.

While in Kosova are missing BIM technologies. Many architects are using BIM software's and producing high performance building designs, but there are missing BIM consultancy specialist that work with a wide variety of clients across the construction industry, using technology to improve the process of designing, building and operating buildings.

Architects in Kosova need integrated BIM in a process of institutional consolidation of planning and construction industry using technologies to have an integrated approach numerous essays and interviews with leading innovators in the field of technology and urban design.

\subsection{Observable evidence of technology and increasing urban data}

As BIM (Building Information Modeling) have broader acceptance in the architecture and engineering of individual and public buildings, perhaps it is time to consider the next scale: spatial planning in the city. Just like buildings virtual models help us design and understand embed information, virtual city simulations could have an application in real city planning, allowing us to go from 2D GIS to three dimensional information modeling that includes terrain, infrastructure, buildings and public spaces.

The role of an architect is to analyze the current state and produce design proposals and give advice for the future based on the information available today. To be able to imagine a new more improved design the architect needs to know relationships between structural elements, stated by laws of physic and logic (Baldwin, C., \& Clark, K. , 2000) In order to deliver the best result the architect collects and evaluates information from different sources, rearranges and produces new information. In addition, the architect evaluates the demands from the customer and simulates the expected impacts that the design will have (Kalay, 2006).

Architects are required to be responsive in order to rapidly react to changing market needs and opportunities. The demand to increase efficiency, decrease costs, reduce time, and increase the turnover are causing construction companies to evaluate and re-think their role in, and way of executing construction projects.

Prefabrication has been around for a long time, and for most of that time it has been touted as the "next big thing" in architecture. Following the advent of Henry Ford's mass production process, the 
concept of prefabrication became a key concept used by such iconic architects as Le Corbusier and Walter Gropius. The concept and practice of fabricating architectural elements off-site is now more important and relevant than ever.

Architects continue to pre-build off-site, out of the weather, out of harm's way, and in the most intelligent manner possible. However, the result needs to be considered, implemented, and promoted with greater sophistication. It is no longer enough to simply re-purpose standard components or to replicate mass-produced architecture. More of the same is just more of the same. Today's tools and technologies allow for the ability to conceive, develop, evaluate, coordinate, build and distribute meaningful work. This becomes the true specialty of the architect and the modern professional has more ability than ever to implement difference in the most intelligent of ways.

The race to build the first 3D-printed house has begun. Architects worldwide are competing to produce the first habitable printed structure, using technology that could transform the way buildings are made. Though they all have the same objective, the teams are investigating very different materials and fabrication methods for printing house that will be printed on site, in concrete.

\subsection{The need for technology and increasing urban data}

Visual models and national codes need information modelling. All information that is currently flowing around in a thousand different channels in one place, built like the architect's a model could accommodate all kinds of useful information such as use areas of buildings, use types, vacancies, lease space, hotel rooms and room availabilities, the age of buildings and if they are historically protected and much much more all the way to the condition of infrastructure or the congestion levels of roads.

In many respects it would be like GIS maps where any number of informational properties can be embedded in shape files including properties that belong in the third dimension, such as heights. Indeed, many city GIS shape files include building heights either transferred by hand from old manual data bases, building heights much like sonar had mapped the sea-floor and ocean depth. The logical steps for cities that have good GIS maps would be the simple "extrusion" of their buildings from the combined footprint shape file combined with the height. This provides what Vancouver's 3D modelling expert Dan Campbell calls 2.5-D, meaning 3 dimensional based on a 2D information base. Such models are not "smart" in the way that they are a real model of a building. Rather, they are like the old lump of clay in the conventional model, they have volume (which architects like to call massing) but don't know floors, have no facades, no windows and no knowledge of floor areas, energy consumption and such that represent more information than area times height equals volume.

Why all this worry when we already have Google Earth? Can't we see our cities in 3D just fine simply by clicking on Google maps and go for the 3D views? (Figure 1) 


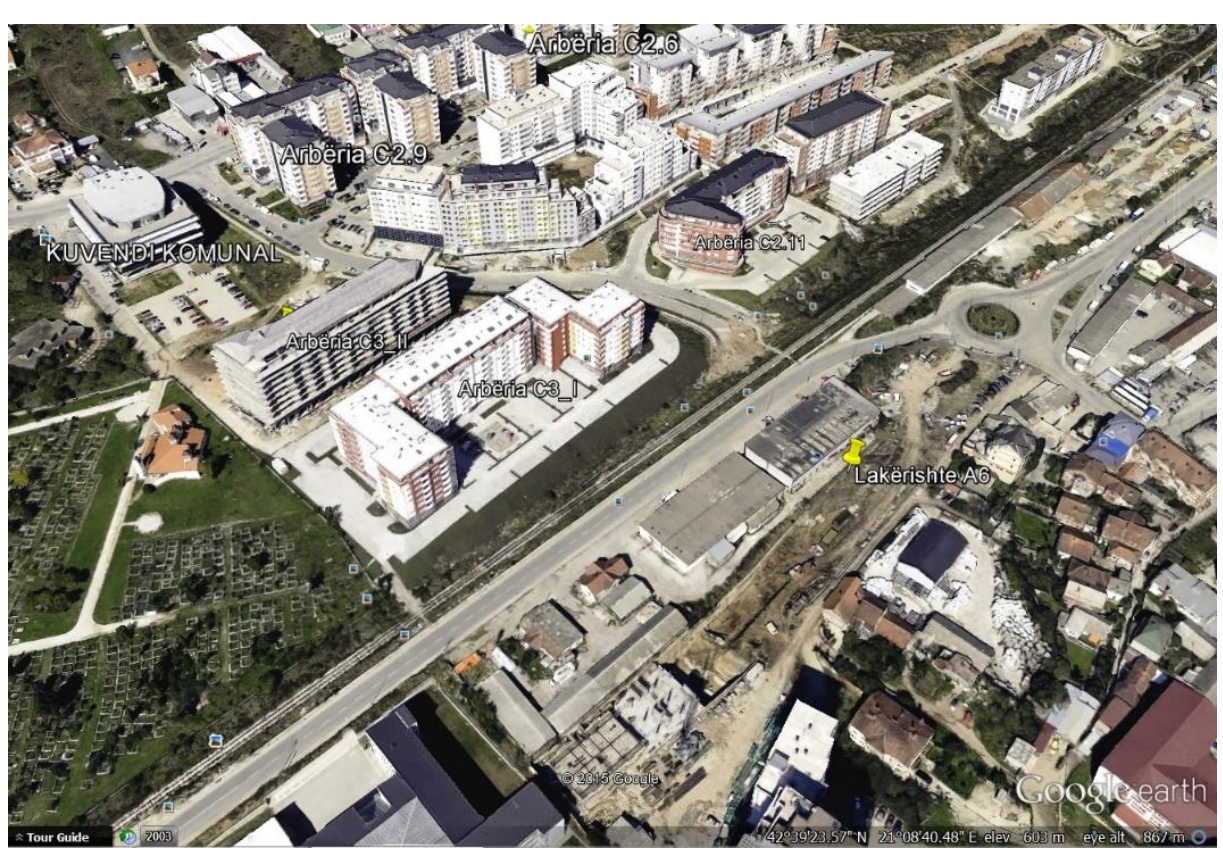

Figure 1 Image of the Google Earth model of Prishtina

Those Google models are an interesting approach because they are largely the result of crowdsourcing as we know it from Wikipedia. People interested in their cities or in particular buildings can build stuff in Sketch-up (the Google software that revolutionized building modeling by offering a basic version free to all and making the process simpler than 3D CAD had ever been before).

\subsection{Why changes}

To answer this question, it is necessary to look in more detail at what architects and planners are doing now. Although the core of global and local, traditional, practices remain, many of the practices had expanded up on the type of work that would traditionally be considered the architect's field, offering a broader range of services. A 3D drawing can be viewed from almost any angle and is therefore easier to interpret than traditional 2D drawings. Additionally, BIMs include information such as detailed descriptions of parts of the building, e.g. characteristics of materials, size and location. With continuallv undated information, the GIS database has become a critical tool in the designing, planning and development. Moreover, information on construction schedules as well as on bills of quantity and cost analysis can be combined. BIM is a modern way to manage the information and design buildings in construction processes. Technical regulations known as CODE-s are dependent from developing technology too. Kosova is in the process of code creation that makes more responsible role of architects in given context.

Virtual Reality is often discussed in indirect opposition to perceived reality and hence is seen to be terrifying, or less meaningful (Champion, 2007). Cyber-architecture is another concept widely discussed in the world of 3D modeling. The development of cyber-architecture suggest the architects to abandon the design of the finished products and start developing virtual interfaces for the customer to keep on designing their own objects, spaces and events (Baltazar, 2007). Broader, the increased use of platform systems has the potential of changing the current strictly hierarchical design process into a network of design, manufacturing, marketing and organizations management, where the responsibility for design is distributed across multiple professions, organizations and geographic locations (Kalay, 2006)

The system was developed in an engineering environment where design problems, although having a simple graphical content, were described in mathematical terminology. Architects claimed that the design situations differed completely from this way of working as they traditionally arranged volumes in space, selecting materials, constructions and environmental systems which required only very little 
amount of computerization (Willey, 1976) . Today, the economic benefits of BIM are widely known in industries as the automotive industry, electronics and consumer goods manufactures. They have used "model-based digital design processes" supp orting not just production planning, and engineering analy sis, but supply-chain integration and visualization of the design (Bernstein, P. G., \& Pittman, J. $\mathrm{H}, 2004)$. The construction industry however still is just starting to see the benefits and challenges an organization faces by deciding to implement BIM. One use of BIM is to provide the customer a glance of how the building will be experienced when finished. The implementation of BIM requires that the architect handle over a digital 3D model of the design done in a compatible program. All participants in the project use a common database to store drawings and exchange information with each other. (Bergmark, 2004; Norén, 2009)

\section{Findings}

Architects role development can be influenced by a number of factors but technology and urban data are changing it in dramatic speed. Globally architects are at a center point where the entire building industry is ready to explode in reaction to changing opportunities. Together with engineers, contractors, and building owners architects are mutually engaged to an unprecedented degree in broad initiatives aimed at improving quality and reducing the cost of designing, constructing, and operating buildings throughout their useful lives. Teamwork and leadership brings all these things together and expresses changed role of the architect.

For students and the vast majority of architects involved in the building industry and urban planning, the future remains only a vision. However, an increasing number are finding ways to implement changes in their business processes and relationships in order to realize the benefits of new technologies. As a result, the perspective point is shifting from simply what should be done to how and when it should be done.

Effects of increased use of technical platform have on the architects' roles is researched from many authors like: (Kalay, 2006) and (Baldwin, C., \& Clark, K. , 2000). They describe the challenge in the modern situation in how to incorporate the architects' knowledge in construction projects.

BIM and urban data is a double-edged blade. While it allows for improved profit potential through replicating tasks and providing quicker detailing, it also is being led by new emerging architects who have not seen or experienced many of the tricks only time and experience will teach. Without thorough coordination prior to beginning construction, the level of quality and completeness becomes an issue. Role of Architect in spatial planning, urban design and construction industries are in high demand. This is because more and more buildings and cities are becoming interested performing in "green", renewal of urban spaces, and increased demand for efficiency of new and their existing spaces. It is the architectural engineer who plans, designs, and oversees how the elements of landscaping, road routing, and building use combine into creating the urban environment. In order to get architecture engineering jobs in an urban setting architect should have an educational background in architectural engineering. The increased technical complexity of construction detailing and new building technology, along with associated risk management, have led to a gradual erosion of architectural roles in favor of the subcontractor and contractor, who will continue to take on an increasingly larger part of the technical design work over the next decade. This trend has intensified as architects look to reduce their liability. The reaction is that they are also increasingly losing influence. It is clear that whichever party accepts the risk in the building process tends to drive the design.

In local context implementing dy namic leadership within a collaborative process allows expertise to be collected from individuals who might not have had input in a traditional delivery environment. There is also a need for changing project delivery methodology that will give architects opportunity in taking control and saving leadership in in planning and construction processes. New approach is needed to influence the experience, talent and input of all team members in order to obtain the best results for the owner by reducing waste and maximizing resources throughout the life cycle of the project. Collaborative process and new project delivery methodology will produce shorter delivery times than traditional practices. The result is a better project that benefits from leadership provided by the architect and applied throughout the entire building process. 


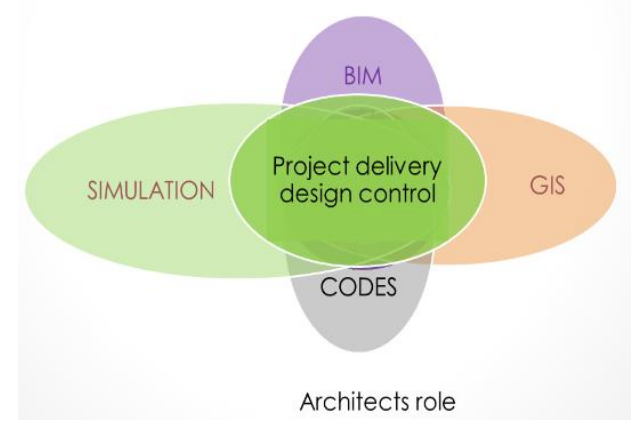

In pressure from global trends the acceptance of BIM tools and methods in the in local architectural design and construction industry is starting to increase, it is time to look beyond the horizon of BIM and see how building information modelled in BIM environments can be combined with information coming from other domains. In this research the focus is made in combination of BIM with simulation, GIS, heritage, and CODE. It is time for local institutions to bring their data to the architectural designer and construction expert. Quantitative researches and institutional data in dynamic technological environment will increase role of architects and their opportunities in taking control management and technical aspects of combining BIM, GIS and CODE with other information.

\section{Conclusions}

For architects and urban planners as for the vast majority of players in the building industry, the future remains only a vision. However, an increasing number are finding ways to implement changes in their business processes and relationships in order to realize the benefits of new technologies. As a result, the conversation is increasingly shifting from simply what should be done to how and when it should be done. Architects role in selection of a project delivery method is an important decision that defines the relationships among the owner, designer and constructor. In the future use of technological tools is chance for architect's main role in influencing these relationships and taking control.

\section{References:}

1. Baldwin, C. \&. (2000). Design Rules - the Power of Modularity. . Bostan: Massachusetts Institute of Technology .

2. Baldwin, C., \& Clark, K. . (2000). Design Rules - the Power of Modularity. Boston: Massachusetts Institute of Technology.

3. Baltazar, A. (2007). Towards a virtual architecture: pushing cybernetics from government to anarchy. Kybernetes, 36 (9/10), 1238-1254.

4. Bernstein, P. G., \& Pittman, J. H. (2004). Barriers to the Adoption of Building Information Modeling in the Building Industry .Autodesk Inc, at all.

5. Champion, E. (2007). When Windmills Turn Into Giants: The Conundrum of Virtual Places. . Technè , 10.

6. Day, A. (1996). The Maquette, the model and the computer: organizational futures for design and construction. Engineering, Construction and Architectural Management, 1-28.

7. Kalay, Y. (2006). The impact of information technology on design methods, products and practices . Design Studies, 27, 357-380.

8. Relph, E. (2007). Spirit of place and Sense of Place in Virtual Realities. Techne, 10 (3).

9. Samuelson, O. (2008). The IT-barometer - a decade's development of IT use in the Swedish construction sector,. ITcon Vol. 13, 1-19.

10. Tweed, C. ( 2001). The social context of CAAD in practice. 617-629. . Automation in Construction, 10, , 617-629.

11. Willey, D. (1976). Approaches to computer-aided architectural sketch design. Computer Aided Design, 8 (3), 181-186. 